\title{
Diversity of parasites in wild Astronotus ocellatus (Perciformes, Cichlidae), an ornamental and food fish in Brazil
}

\author{
MARCOS TAVARES-DIAS ${ }^{1,2}$ and LIGIA R. NEVES ${ }^{2}$ \\ ${ }^{1}$ Embrapa Amapá, Rodovia Juscelino Kubitschek, Km 5, № 2600, 68903-419 Macapá, AP, Brazil \\ ${ }^{2}$ Programa de Pós-Graduação em Biodiversidade e Biotecnologia - PPGBIONORTE, Universidade \\ Federal do Amapá/UNIFAP, Rodovia Juscelino Kubitschek, s/n, 68903-419 Macapá, AP, Brazil
}

Manuscript received on October 14, 2016; accepted for publication on June 12, 2017

\begin{abstract}
The community composition of parasites was characterized in Astronotus ocellatus from a tributary of the Amazon River, northern Brazil. The prevalence was $87.9 \%$, and a total of 526,052 parasites were collected, with a mean of 15,941 parasites per host. Nine taxa of ecto- and endo-parasites were identified, but Ichthyophthirius multifiliis was the dominant species, while Piscinoodinium pillulare, Clinostomum marginatum and Argulus multicolor were the least prevalent parasites. The parasite community was characterized by a low species richness, low diversity and low evenness. Host body size was not found to influence the composition of the parasite community, and there was no significant correlation between abundance of any parasite species and host body size. Papers published concerning the presence of parasites in this host in different hydrographic basins within Brazil indicate that 22 species of parasites are known to infect $A$. ocellatus, including species of ectoparasites and endoparasites. In Brazil, ectoparasites species, particularly crustaceans, have been found to parasitize A. ocellatus in relatively high numbers. This predominance of ectoparasites is typical of fish of lentic ecosystems. Finally, the presence of different endoparasites taxa suggest that $A$. ocellatus acts as an intermediate or definitive host.
\end{abstract}

Key words: aggregation, Amazon, ectoparasites, endoparasites, freshwater fish.

\section{INTRODUCTION}

Astronotus ocellatus Agassiz, 1831, commonly known as the Oscar, is a species of Cichlidae native to the Amazon River basin, including Brazil, Peru, Colombia and French Guyana (Soares et al. 2011, Tavares-Dias et al. 2014, Froese and Pauly 2017). This fish has also been introduced to some river basins in northeast and southern Brazil (Azevedo et al. 2007). The Oscar is of great economic

Correspondence to: Marcos Tavares-Dias

E-mail: marcos.tavares@embrapa.br interest, mainly for aquarium hobbyists and sport fishing, and is an important food item for riverine populations from the Amazon (Soares et al. 2011). It is popular as an ornamental fish due to its exotic coloration and natural reproduction in captivity, and as such it is cultured in countries around the world (Tavares-Dias et al. 2014).

Astronotus ocellatus is a benthopelagic cichlid that prefers lentic environments, finding protection under submerged branches and trunks. It is an omnivorous species, although its diet is heavily 
composed of fish, crustaceans, gastropods and larvae of aquatic insects, and its behavior includes ambush and capture of prey and avoiding predators by escaping over short distances (Azevedo et al. 2007, Soares et al. 2011, Tavares-Dias et al. 2014, Froese and Pauly 2017). In the Amazon region, spawning occurs between the onset of river flooding in the rainy season (December) and the beginning of the dry season, and first gonadal maturation occurs at a length of $25 \mathrm{~cm}$, when the fish is between 15 and 24 months old (Soares et al. 2011).

Over 400 helminth species are known from cichlids, an underestimation of the actual diversity, with substantial differences in species richness between different continents and parasite taxa. Parasitic diseases are important drivers of ecological interactions and evolution (Vanhove et al. 2016). Owing to the almost worldwide distribution of this species due to introductions, its occurrence in a wide variety of habitats, its omnivorous nature and its central position in the food web, A. ocellatus has been much used as a model in ecological parasitology studies in South America, and particularly in some hydrographic basins in Brazil (Azevedo et al. 2007, Neves et al. 2013, Tavares-Dias et al. 2014). However, these studies have not yet been reviewed and analysed to synthesize information on parasite diversity in $A$. ocellatus. The first of these studies was conducted by Malta (1982a), who reported the presence of Dolops bidentata Bouvier, 1899 and Dolops geayi Bouvier, 1897 in A. ocellatus in the AmazonSolimões River.

Studies of the parasites of fish improve knowledge of parasite-host-environment interactions (Tavares-Dias et al. 2014, MorozińskaGogol 2015, Cirtwill et al. 2016), and can help to indicate the feeding habits of host fish. Most host fish species have particular associated parasite communities living within or on their bodies during different life-cycle stages, with speciesspecific variations in prevalence and abundance.
The hosts provide food and other specific resources for obligate or temporary parasites (Azevedo et al. 2007, Neves et al. 2013, Tavares-Dias et al. 2014). Consequently, host fish are entire habitats for parasites, attending to all of the parasites' needs. Factors influencing parasite richness and abundance at the individual host level form the basis of parasitic infection patterns (Losee et al. 2014, Morozińska-Gogol 2015, Cirtwill et al. 2016).

This study has two main aims: 1) to characterize the parasite community of $A$. ocellatus in a tributary of the Amazon River, and 2) to gather and analyze data on the diversity of parasites in wild populations of this host, and the parasite infracommunity and community structure, described in studies conducted in Brazil.

\section{MATERIALS AND METHODS}

\section{STUDY AREA}

The study was conducted in the Fortaleza Igarapé basin (Figure 1), a tributary of the Amazon River in the state of Amapá (Brazil). The study area is influenced by semi-diurnal tidal inundations, and by large seasonal variation in rainfall levels. The waters that periodically spread out across the floodplain are rich in nutrients, because of the rapid decomposition of grasses, animal remains and the humus layer of the forest. This leads to growth of new vegetation (Poaceae, Cyperaceae, Fabaceae, Onagraceae, Araceae, Asteraceae, Convolvulaceae and Lentibulariaceae) and a high biomass of invertebrates (insects, zooplanktonic crustaceans and mollusks), which are important food items for fish. The basin of the Fortaleza Igarapé is highly complex and its regulation is a process that affects the river-floodplain system, as well as fish movement and community structure. Moreover, this tributary is suffering strong impacts 


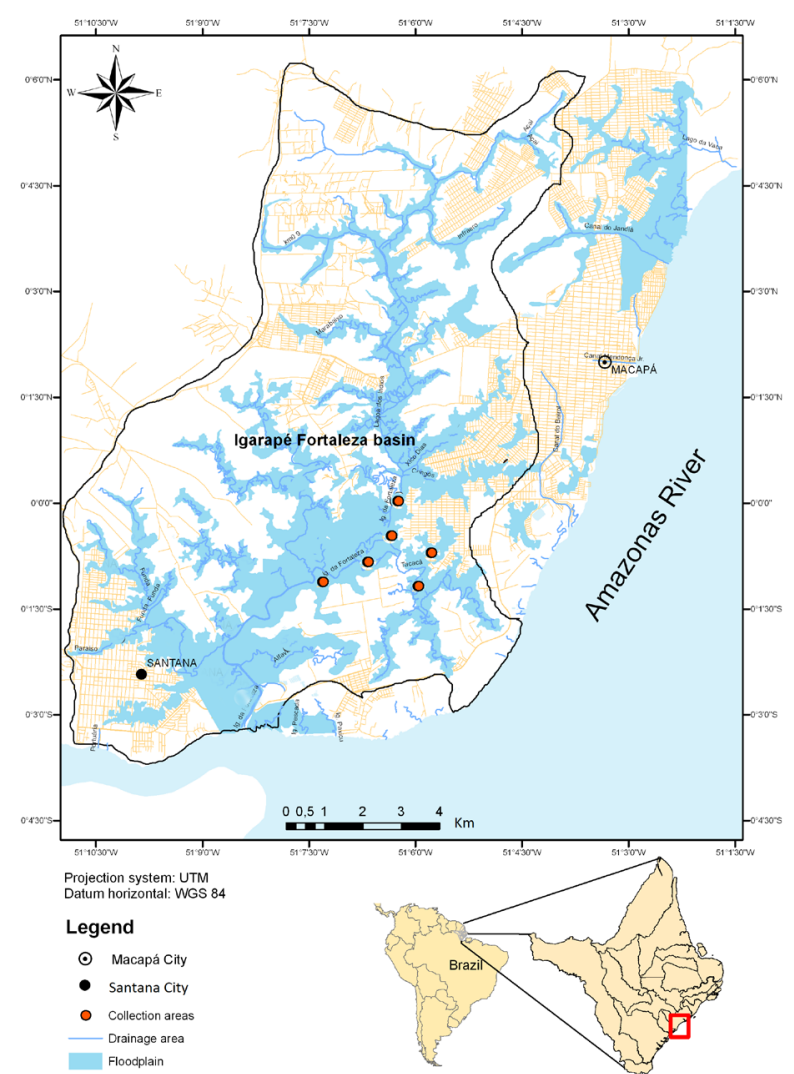

Figure 1 - Collection sites of Astronotus ocellatus from the Fortaleza Igarapé basin, in the eastern Amazon (Brazil).

of urbanization, principally in floodplain areas (Gama and Halboth 2004, Takiyama et al. 2012).

\section{FISH COLLECTION}

Between February and November 2013, 33 specimens of $A$. ocellatus were caught in gillnets of different mesh sizes (ICMBio authorization number: 23276-1), from the basin of the Fortaleza Igarapé. The fish were then transported to the Laboratory for Aquatic Organism Health at Embrapa Amapá in insulated boxes containing ice. This study was developed in accordance with the principles adopted by the Brazilian College of Animal Experimentation (COBEA) and with authorization from the Ethics Committee in the Use of Animals of Embrapa Amapá (\# 004 - CEUA/ CPAFAP) and ICMBio (\# 23276-1).

\section{PARASITE COLLECTION AND ANALYSIS}

The fish specimens were weighed $(\mathrm{g})$ and their total length was measured $(\mathrm{cm})$. Each specimen was then evaluated macroscopically, observing the body surface, mouth, eyes, opercula and gills. The gills were removed to collect ectoparasites. The gastrointestinal tract and viscera was removed and examined in order to collect endoparasites. The parasite specimens were collected, fixed, quantified and stained for identification (Eiras et al. 2006).

The ecological terms used followed previous recommendations (Rohde et al. 1995, Bush et al. 1997). The Brillouin index $(H B)$, evenness $(E)$ and species richness (Magurran 2004) were calculated for each component of the parasite community, using the software Diversity (Pisces Conservation Ltd, UK). The dispersion index (ID) and discrepancy index (D) were calculated using the software Quantitative Parasitology 3.0, in order to detect the distribution pattern of the parasite infracommunities (Rózsa et al. 2000), for species with prevalence $>10 \%$. The significance of ID, for each infracommunity, was tested using the $d$ statistic (Ludwig and Reynolds 1988).

The body mass (Wt; g) and total length $(\mathrm{Lt} ; \mathrm{cm})$ data were used to calculate the relative condition factor $(\mathrm{Kn})$ of the host fish using the length-weight relationship ( $\left.W=\mathrm{aL}^{\mathrm{b}}\right)$ after logarithmic transformation of length and weight and subsequent adjustment of two straight lines, thereby obtaining $\ln y=\ln A+B \ln x($ Le Cren 1951). Spearman's coefficient $(r s)$ was used to investigate the correlation between: i) host body length and parasite species richness, ii) $H B$ and parasite abundance, and iii) host relative condition factor and parasite species richness (Zar 2010).

A review on the parasites of $A$. ocellatus in Brazil by searching databases (SciELO, ISI, Scopus, Science Direct and Google Scholar) was performed, and available data regarding the parasitic fauna were added to Table. 
TABLE I

Parasite infracommunities of Astronotus ocellatus from Igarapé Fortaleza basin, in the eastern Amazon (Brazil). P: Prevalence; MA: Mean abundance; SI: Site of infection. MI: Mean intensity, FD: Frequency of dominance, TNP: Total number of parasites.

\begin{tabular}{|c|c|c|c|c|c|c|}
\hline Parasite taxa & SI & $\mathrm{P}(\%)$ & MI (Range) & $\mathrm{MA} \pm \mathrm{SD}$ & $\mathrm{FD}(\%)$ & TNP \\
\hline Ichthyophthirius multifiliis & Gills & 51.5 & $30,614.4(2646-148896)$ & $15,771 \pm 34,759.1$ & 0.99 & 520,444 \\
\hline Piscinoodinium pillulare & Gills & 3.0 & $3818(0-3818)$ & $115.7 \pm 664.6$ & 0.007 & 3818 \\
\hline Gussevia asota & Gills & 57.7 & $56.5(1-201)$ & $32.5 \pm 48.8$ & 0.002 & 1073 \\
\hline $\begin{array}{l}\text { Postodiplostomum sp. } \\
\text { (metacercariae) }\end{array}$ & Gills & 48.5 & $34.2(1-150)$ & $16.6 \pm 30.6$ & 0.001 & 547 \\
\hline $\begin{array}{c}\text { Clinostomum marginatum } \\
\text { (metacercariae) }\end{array}$ & Intestine & 3.0 & $2.0(0-2)$ & $0.1 \pm 0.3$ & - & 2 \\
\hline $\begin{array}{c}\text { Thometrema sp. } \\
\text { (metacercariae and adults) }\end{array}$ & Intestine & 9.1 & $33.3(4-91)$ & $3.0 \pm 15.8$ & 0.0002 & 100 \\
\hline Contracaecum sp. (larvae) & Intestine & 24.2 & $1.9(1-4)$ & $0.5 \pm 1.0$ & - & 15 \\
\hline $\begin{array}{c}\text { Proteocephalus gibsoni } \\
\text { (larvae) }\end{array}$ & Intestine & 33.3 & $4.7(1-16)$ & $1.6 \pm 3.6$ & - & 52 \\
\hline Argulus multicolor & Gills & 3.0 & $1.0(0-1)$ & $0.03 \pm 0.2$ & - & 1 \\
\hline
\end{tabular}

\section{RESULTS}

PARASITE COMMUNITY OF A. ocellatus IN THE FORTALEZA IGARAPÉ BASIN

Nine taxa of ecto- and endo-parasites were found in the 33 specimens of $A$. ocellatus, prevalence was $87.9 \%$ and a total of 526,052 parasites were collected. The mean number of parasites per fish was 15,941 , with a strong predominance of ectoparasites (mean of 15,935.8 per fish, cf. mean of 2.1 endoparasites per fish). Species of Protozoa, Monogenoidea, Digenea, Cestoda, Nematoda and Crustacea were collected from host specimens. The dominant species was Ichthyophthirius multifiliis Fouquet 1876, followed by metacercariae (Posthodiplostomum sp.) and Gussevia asota Kritsky, Thatcher and Boeger 1989, while Piscinoodinium pillulare Schäperclaus, 1954, Lom 1981, Clinostomum marginatum Rudolphi, 1819 and Argulus multicolor Stekhoven, 1937 were the least prevalent parasites (Table I).

The parasite species of $A$. ocellatus presented an aggregated dispersion (Table II), which is a common distribution pattern for freshwater fish.
Brillouin diversity index varied from $0.0005-$ 0.89 , evenness from $0.0002-0.41$ and parasite species richness varied from 1-6 parasites (Table III), but the predominance was of hosts infected by between 2 and 4 species (Figure 2). There was no significant correlation between host length and the Brillouin index $(r s=0.11, \mathrm{p}=0.55)$, or parasite species richness $(r s=0.22, \mathrm{p}=0.22)$. There was also no significant correlation between host relative condition factor and parasite species richness ( $r s=$ $0.29, \mathrm{p}=0.09$ ).

The relative condition factor of the hosts varied from 0.93-1.06 (Table III), and there was no difference $(\mathrm{t}=-0.02, \mathrm{p}=0.99)$ in the standard value $(\mathrm{K}=1.00)$. In $A$. ocellatus, the weight-length relationship of parasitized and non-parasitized fish showed negative allometric growth (Figure 3), which indicates a larger increase in body mass than length.

There was a weak correlation between the abundance of Postodiplostomum sp. and host weight and $\mathrm{Kn}$, and between the abundance of Contracaecum sp. and host weight and length (Table IV). 
TABLE II

Index of dispersion (ID), $d$-statistic and discrepancy index (D) for the parasite infracommunities of Astronotus ocellatus from the Fortaleza Igarapé basin, in the eastern Amazon (Brazil).

\begin{tabular}{lcccc}
\hline Parasite taxa & ID & $d$ & D & Dispersion \\
\hline Ichthyophthirius multifiliis & 3.38 & 6.77 & 0.63 & Aggregated \\
Gussevia asota & 3.26 & 6.51 & 0.59 & Aggregated \\
Postodiplostomum sp. & 2.95 & 5.79 & 0.63 & Aggregated \\
Contracaecum sp. & 1.74 & 2.60 & 0.79 & Aggregated \\
Proteocephalus gibsoni & 2.33 & 4.26 & 0.74 & Aggregated \\
\hline
\end{tabular}

TABLE III

Descriptors of diversity and body parameters for parasites communities of Astronotus ocellatus from the Fortaleza Igarapé basin, in the eastern Amazon (Brazil).

\begin{tabular}{cc}
\hline Mean indices & Mean \pm SD (Range) \\
\hline Length $(\mathrm{cm})$ & $20.7 \pm 2.7(13.3-25.0)$ \\
Weight $(\mathrm{g})$ & $207.6 \pm 66.1(59.4-330.0)$ \\
Condition factor $(\mathrm{Kn})$ & $0.99 \pm 0.03(0.93-1.06)$ \\
Species richness & $2.3 \pm 1.6(1-6)$ \\
Brillouin $(H B)$ & $0.11 \pm 0.22(0.0005-0.89)$ \\
Evenness $(E)$ & $0.05 \pm 0.10(0.0002-0.41)$ \\
\hline
\end{tabular}

TABLE IV

Spearman's correlation coefficient ( $r s$ ) for the abundance of parasites with the total length, body weight and relative condition factor (Kn) of Astronotus ocellatus from the Fortaleza Igarapé basin, in the eastern Amazon (Brazil).

\begin{tabular}{lcccccc}
\hline & \multicolumn{2}{c}{ Length } & \multicolumn{2}{c}{ Weight } & \multicolumn{2}{c}{ Kn } \\
\hline Parasites & rs & $\mathrm{p}$ & rs & $\mathrm{p}$ & rs & $\mathrm{p}$ \\
\hline Ichthyophthirius multifiliis & 0.10 & 0.57 & 0.15 & 0.39 & 0.08 & 0.63 \\
Gussevia asota & -0.09 & 0.62 & -0.003 & 0.98 & 0.16 & 0.37 \\
Postodiplostomum sp. & 0.19 & 0.28 & 0.39 & $\mathbf{0 . 0 2}$ & 0.44 & $\mathbf{0 . 0 1}$ \\
Contracaecum sp. & 0.35 & $\mathbf{0 . 0 4}$ & 0.38 & $\mathbf{0 . 0 3}$ & 0.14 & 0.44 \\
Proteocephalus gibsoni & 0.08 & 0.66 & 0.06 & 0.74 & 0.14 & 0.43 \\
\hline
\end{tabular}

TABLE V

List of parasites in Astronotus ocellatus from different hydrographic basis in Brazil.

\begin{tabular}{lll}
\hline Parasite taxa & Locality of collection & References \\
\hline $\begin{array}{l}\text { Protozoa } \\
\text { Ichthyophthirius multifiliis Fouquet, 1866 }\end{array}$ & Pracuúba Lake (AP) & Neves et al. (2013) \\
$\begin{array}{l}\text { Piscinoodinium pillulare Schaperclaus, 1954 } \\
\text { Trichodina } \text { sp. }\end{array}$ & Pracuúba Lake (AP) & Neves et al. (2013) \\
$\begin{array}{l}\text { Monogenoidea } \\
\text { Gussevia asota } \text { Kritsky, Thatcher and Boeger, 1989 }\end{array}$ & Janauacá Lake (AM) & Neves et al. (2013) \\
& Guandu River (RJ) & Kritsky et al. (1989) \\
& Arevedo et al. (2007, 2010, 2011), \\
$\begin{array}{l}\text { Gussevia astronoti } \text { Kritsky, Thatcher and } \text { Boeger, } \\
1989\end{array}$ & Janauacá Lake (AM) & Neves et al. (2013) \\
\hline
\end{tabular}


TABLE V (continuation)

\begin{tabular}{|c|c|c|}
\hline Parasite taxa & Locality of collection & References \\
\hline & Guandu River & $\begin{array}{l}\text { Azevedo et al. (2007, 2011), Abdallah et } \\
\text { al. (2008) }\end{array}$ \\
\hline & Pracuúba (AP) & Neves et al. (2013) \\
\hline \multirow[t]{2}{*}{$\begin{array}{l}\text { Gussevia rogersi Kritsky, Thatcher and Boeger, } \\
1989\end{array}$} & Solimões River (AM) & Kritsky et al. (1989) \\
\hline & Pracuúba (AP) & Neves et al. (2013) \\
\hline \multicolumn{3}{|l|}{ Nematoda } \\
\hline \multirow[t]{3}{*}{ Contracaecum sp. larvae } & Guandu River (RJ) & Azevedo et al. $(2007,2010,2011)$ \\
\hline & Pracuúba (AP) & Neves et al. (2013) \\
\hline & Coari Grande River (AM) & Tavares-Dias et al. (2014) \\
\hline $\begin{array}{l}\text { Procamallanus (Spirocamallanus) inopinatus } \\
\text { Travassos, Artigas and Pereira, } 1928\end{array}$ & Coari Grande River (AM) & Tavares-Dias et al. (2014) \\
\hline \multicolumn{3}{|l|}{ Digenea } \\
\hline \multirow[t]{2}{*}{ Posthodiplostomum sp. } & Pracuúba Lake (AP) & Neves et al. (2013) \\
\hline & Coari Grande River (AM) & Tavares-Dias et al. (2014) \\
\hline Herpetodiplostomum sp. & Pracuúba Lake (AP) & Neves et al. (2013) \\
\hline \multicolumn{3}{|l|}{ Acanthocephala } \\
\hline Polimorphus sp. & Guandu River (RJ) & Azevedo et al. $(2007,2010,2011)$ \\
\hline \multicolumn{3}{|l|}{ Cestoda } \\
\hline Proteocephalus gibsoni Rego and Pavanelli, 1990 & Amazon River (AM) & Rego and Pavanelli (1990) \\
\hline \multicolumn{3}{|l|}{ Crustacea } \\
\hline Dolops bidentata Bouvier, 1899 & Solimões River (AM) & Malta (1982a, 1984) \\
\hline Dolops geayi Bouvier, 1897 & Solimões River (AM) & Malta (1982b, 1984) \\
\hline Dolops discoidalis Bouvier, 1899 & Solimões River(AM) & Malta (1984) \\
\hline Dolops nana Lemos de Castro, 1959 & Pracuúba Lake (AP) & Neves et al. (2013) \\
\hline Lamproglena monodi Capart, 1944 & Guandu River (RJ) & Azevedo et al. $(2007,2010,2011,2012)$ \\
\hline Argulus sp. & Solimões River (AM) & Malta (1984) \\
\hline \multicolumn{3}{|l|}{ Hirudinea } \\
\hline Placobdella sp. & Guandu River (RJ) & Azevedo et al. $(2007,2010,2011)$ \\
\hline
\end{tabular}

PARASITE INFRACOMMUNITY STRUCTURE, ACROSS BRAZIL

The parasite fauna reported is composed by 2 species of Protozoa, 3 Monogenoidea, 2 Nematoda, 2 Digenea, 1 Acanthocephala, 1 Cestoda, 6 Crustacea and 1 Hirudinea (Table V).

\section{DISCUSSION}

The parasite community of $A$. ocellatus in the Fortaleza Igarapé basin was found to be composed of 9 parasites species: 2 species of protozoans, 1 monogenoidean, 3 digeneans, 1 nematode, 1 cestode and 1 crustacean, and presented an overdispersion distribution pattern, low species richness, low diversity and low evenness. Ichthyophthirius multifiliis was the dominant parasite. About $65 \%$ of the parasites found here are in common with previous records of the parasite community of this host species. However, the results of this study represent the first record of A. multicolor, Thometrema sp., C. marginatum and $P$. gibsoni as parasites of $A$. ocellatus. Species of protozoans, monogenoideans, nematodes, digeneans, acanthocephalans, cestodes, 


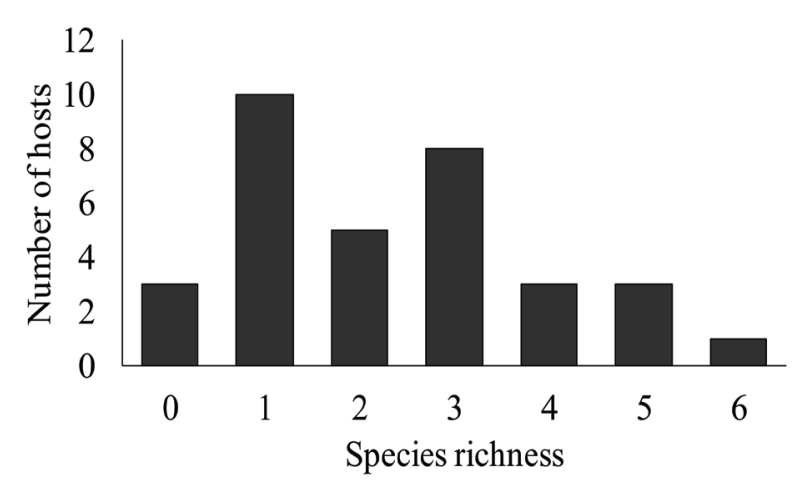

Figure 2 - Species richness of parasites in Astronotus ocellatus from the Fortaleza Igarapé basin, in eastern Amazon (Brazil).

crustaceans and hirudineans constitute the parasite community of wild A. ocellatus across Brazil, and the presence of these parasites differs between basins, due to geographic variation in abiotic and biotic environmental factors. Fish are the vertebrates that host the highest diversity of parasite species, as aquatic systems facilitate parasite reproduction, dispersion, survival and life history, and abundant host species like A. ocellatus usually tend to harbour a richer parasitofauna (Morozińska-Gogol 2015).

There are 22 parasite species known for A. ocelaltus in Brazil, and this is probably an underestimation of the actual diversity, due to differences in species richness of parasites for different hydrographic basins. Some composition and structural patterns were here detected in the parasite community of $A$. ocellatus in the different basins in Brazil, including: (a) dominance of $G$. asota and Gussevia astronoti Kritsky, Thatcher and Boeger 1989; (b) dominance of ectoparasite species with crustacean infracommunities more diverse than other ectoparasites; (c) overdispersion of ectoparasites and endoparasites, (d) interspecific associations in the ectoparasite infracommunities, specifically a combination of generalist and specialist parasites that should contribute to host population control (e.g. G. asota) and (f) correlation between parasites abundance and host total body size at the infracommunity level.

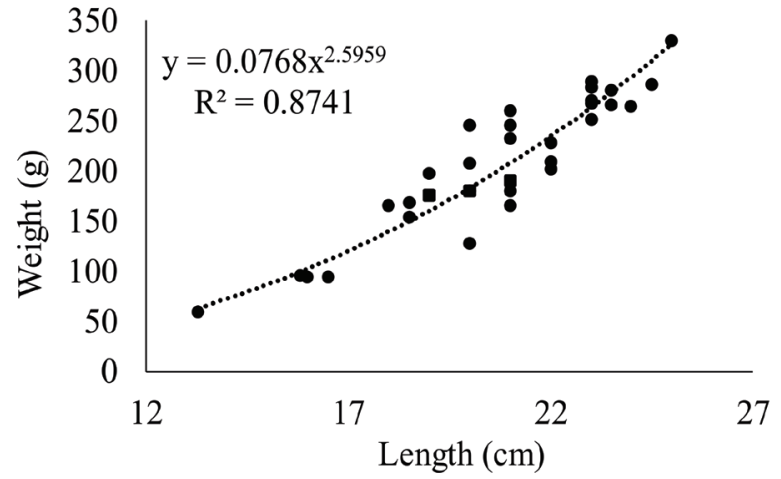

Figure 3 - Weight-length relationship for Astronotus ocellatus from the Fortaleza Igarapé basin, in the eastern Amazon (Brazil) parasitized (1) and non-parasitized (n).

Structure and composition of the parasite community in individual hosts of any given fish population are made up of a set of parasite species available in the environment (Marcogliese et al. 2006, 2016, Losee et al. 2014), and are influenced by many local factors, including environmental and climatic conditions, intensity of food capture by the host, structure of the local food chain, availability of parasites in larval stages, and the presence of adequate intermediate hosts in the environment (Marcogliese et al. 2006, 2016, Losee et al. 2014, Cirtwill et al. 2016). Therefore, although endoparasites acquisition is strongly related to host diet, other factors that vary among different ecosystems also influence the relationship between parasite species richness, parasite load and host fish diet (Cirtwill et al. 2016).

Other ecological factors and attributes of the host population can also influence the abundance and diversity of parasites infecting fish at the individual level, including host age or size (Neves et al. 2013, Cirtwill et al. 2016). Here however, the correlation between $A$. ocellatus size and the abundance of larvae of Postodiplostomum sp. and Contracaecum sp., was only weakly positive. Fish are hosts to diverse ecto - and endoparasite species that can significantly affect their behavior, metabolism, fecundity, growth, survival and body condition. Studies on body condition or welfare 
generally use length and body mass relationships of hosts, assuming that heavier fish of a given length are in better condition (Guidelli et al. 2011, Losee et al. 2014, Lagrue and Poulin 2015). However, fish welfare is a complex concept and it can be approached from nutritional, biological and health perspectives. While high intensity or abundance of parasites can have pathological effects that reduce growth and condition of hosts (Guidelli et al. 2011), other results suggest that diversity of parasites, but not their overall intensity or abundance is related to fish growth and body condition (Losee et al. 2014). In this study, for A. ocellatus individuals infected with predominantly ectoparasites, body condition was not affected. Although, currently, our understanding on aspects of fish body condition is growing (see Guidelli et al. 2011, Losee et al. 2014, Lagrue and Poulin 2015), we still have a limited understanding of the consequences of parasite load on body condition of hosts. Indeed, a better understanding of these potential impacts on wild fish populations could help to mitigate economic losses in fisheries and encourage fish farmers to implement interventions that enhance the welfare of fish, increasing productivity and profits.

In this study, the A. ocellatus specimens collected from the Fortaleza Igarapé basin were mainly collected from the floodplains, which provide important feeding and nursery zones for this species. The floodplains are influenced by semidiurnal tidal inundations that carry organic matter from the Amazon River, and are being strongly affected by urban eutrophication (Gama and Halboth 2004, Taiyama et al. 2012) and invasion of Oreochromis niloticus (Bittencourt et al. 2014). In this population of $A$. ocellatus we found a predominance of ectoparasites such as $G$. asota, I. multifiliis and Posthodiplostomum sp. (but not $P$. pillulare). Infection levels by Posthodiplostomum sp., G. asota and I. multifiliis were similar to those reported by Neves et al. (2013) for A. ocellatus from Pracuúba Lake, another area that is strongly influenced by seasonal variation in Amazonian rainfall. Poor environmental conditions favor the dispersal and survival of some ectoparasite species with free-swimming stages in their life cycles (Dogiel 1961, Marcogliese et al. 2006, Neves et al. 2013). Parasites are frequent in wild populations, including in ornamental fish, and may cause economic losses to the aquarium and fishing industries. Thus, identifying which processes influence parasite distribution among host populations, and host susceptibility to infection, is a central question in parasite ecology (Losee et al. 2014, Morozińska-Gogol 2015, Cirtwill et al. 2016). Recently, Šmiga et al. (2016) described massive infection of G. asota in A. ocellatus in pet-shops and aquarium fish breeders in Slovakia, Europe. In addition, these authors reported that the fish presented visible asphyxia, neurological symptoms, uncoordinated locomotion and sudden death, and high mortality of juveniles.

In this study, infestation of $A$. multicolor on gills of $A$. ocellatus was low and sporadic accidental. Monogenoideans and I. multifiliis are common ectoparasites in freshwater fish and can infect species of all major fish groups worldwide (Dogiel 1961, Neves et al. 2013), but I. multifiliis is an opportunistic parasite (Dogiel 1961, Neves et al. 2013). Gussevia Kohn and Paperna, 1964 are Neotropical monogenoideans that include ectoparasites mainly of cichlid species (Abdallah et al. 2008). For A. ocellatus, Gussevia asota, G. astronoti and G. rogersi are common monogenoidean parasites; however, in the basin of the Fortaleza Igarapé we found only G. asota. Infection by these ectoparasites often gives an indication of the quality of the environment, as parasite abundance and diversity generally increase or decrease in more highly modified environments, such as the Fortaleza Igarapé basin. Therefore, environmental stress plays a major role in parasite abundance, and disease outbreaks may occur due to sudden environmental changes. 
Endohelminth parasites have complex life cycles that are embedded within food webs, relying on consumption of infected prey by predators, in order to reach their next host. Consequently, richness and abundance of these trophically transmitted parasites can be largely explained by the diversity and number of different prey consumed, or intermediate hosts that are prey items within the diet of fish populations (Cirtwill et al. 2016). Proteocephalus gibsoni, a proteocephalid cestode of cichlid species (Rego and Pavanelli 1999, Chambrier et al. 2006), was found at moderate levels of infection in A. ocellatus in this study. However, Goezia spinulosa Diesing, 1839, an endoparasite of Arapaima gigas that infected $A$. ocellatus in fish farms has not been found in wild populations of this cichlid. Indeed, the infection of farmed A. ocellatus occurred because they were fed with plankton from ponds of A. gigas containing larvae of G. spinulosa (Freitas and Lent 1946). Therefore, such results indicate the complex life cycle of this nematode species, as well as its low host specificity. The trematodes of freshwater fish from Brazil have been studied for almost a century. Larval stages (metacercariae) of trematodes are most commonly associated with intermediate hosts. However, life cycle stages of digenean species are generally little-known, limiting knowledge on trematodes infecting fish. The most well documented metacercariae in South American fish belong mainly to the families Diplostomidae, Heterophyidae and Echinostomatidae, which in general use fish-eating birds and aquatic mammals as definitive hosts (Choudhury et al. 2016). In this study, metacercariae of Posthodiplostomum sp. were found on the gills, and of $C$. marginatum in the intestine of $A$. ocellatus. However, these 2 larval digeneans did not exhibit similar prevalence and abundance, probably because of differences in specificity of primary intermediate hosts and asexual reproduction, although both parasites use fish-eating birds as definitive hosts (Ritossa et al.
2013, Pinto et al. 2015). This is the first report of C. marginatum for A. ocellatus.

Studies on digenean parasites of South American fish have recorded the presence of Thometrema overstreeti Brooks, Mayes and Thorson, 1979 and Thometrema magnificum Szidat, 1954, Gibson and Bray, 1979, Thometrema bonariense Lunaschi, 1989 in characid, erythrinid, pimelod and loricariid fish (Kohn et al. 2007). Furthermore, recently, Rassier et al. (2015) found $T$. overstreeti infecting the cichlid Geophagus brasiliensis in an estuary in the state of Rio Grande do Sul (Brazil). In North America Thometrema lotzi Curran, Overstreet and Font, 2002 was described infecting centrarchid fish of freshwater and brackish areas in coastal Mississippi and Louisiana, USA (Curran et al. 2002). Thometrema lotzi is the single species of a genus commonly found in various centrarchid species in the northern Gulf of Mexico drainages (Choudhury et al. 2016). However, this study reports Thometrema sp. as a parasite of A. ocellatus for the first time, and this is a new species of this derogenid.

\section{CONCLUSIONS}

The parasite community of A. ocellatus was characterized by a low species richness, low diversity and low evenness, with a predominance of ectoparasite species and presence of endohelminths in the larval stage, indicating that the diet of this fish includes mollusks and crustaceans. Furthermore, the low richness of endohelminths suggest that this host is occupying a low position in food web, serving as an intermediate and definitive host. The abundance of some parasite species was weakly correlated (correlation coefficient $<50 \%$ ) with host body size, while most species exhibited no correlation with host body size. Finally, the results of the reviewed papers published concerning the presence of parasites in A. ocellatus in different basins of Brazil indicate that, so far, 22 species of 
parasite, belonging to the Protozoa, Monogenoidea, Nematoda, Digenea, Acanthocephala, Cestoda, Crustacea and Hirudinea have been reported for this host. No correlation between parasite infection and fish mortality has been reported. Ectoparasites are by far more common than endoparasites, and Crustacea are the most commonly reported ectoparasites in studies of $A$. ocellatus. Differences observed among studies can be attributed to abiotic and biotic environmental factors resulting from the geographic separation of basins with occurrence of A. ocellatus.

\section{ACKNOWLEDGMENTS}

The authors are grateful to the Coordenação de Aperfeiçoamento de Pessoal de Nível Superior (CAPES, Brazil) for the scholarship granted to the second author and to the Conselho Nacional de Desenvolvimento Científico e Tecnológico (CNPq, Brazil) for supporting a Research Fellowship for M. Tavares-Dias (\#303013/2015-0).

\section{REFERENCES}

ABDALLAH VD, AZEVEDO RK AND LUQUE JL. 2008. Notes on the morphology of two species of Gussevia Kohn and Paperna (Monogenea: Dactylogyridae) parasite on Astronotus ocellatus (Agassiz) (Perciformes: Cichlidae) from Brazil. Panamjas 3(2): 101-104.

AZEVEDO RK, ABDALLAH VD AND LUQUE JL. 2007. Ecologia da comunidade de metazoários do apariari Astronotus ocellatus (Cope, 1872) (Perciformes: Cichlidade) do Rio Gandu, Estado do Rio de Janeiro, Brasil. Rev Brasil Parasitol Vet 16: 15-20.

AZEVEDO RK, ABDALLAH VD AND LUQUE JL. 2010. Acanthocephala, Annelida, Arthropoda, Myxozoa, Nematoda and Platyhelminthes parasites of fishes from the Guandu River, State of Rio de Janeiro, Brazil. Check List 6(4): 659-667.

AZEVEDO RK, ABDALLAH VD AND LUQUE JL. 2011. Biodiversity of fish parasites from Guandu River, Southeastern Brazil: an ecological approach. Neotrop Helminthol 5(2):185-199.

AZEVEDO RK, ABDALLAH VD, SILVA RJ, AZEVEDO TM, MARTINS ML AND LUQUE JL. 2012. Expanded description of Lamproglena monodi (Copepoda
Lernaeidae), parasitizing native and introduced fishes in Brazil. Rev Brasil Parasitol Vet 21(3): 263-269.

BITTENCOURT LS, SILVA URL, SILVA LMA AND TAVARES-DIAS M. 2014. Impact of the invasion from Nile tilapia on natives Cichlidae species in tributary of Amazonas River, Brazil. Biota Amaz 4: 88-944.

BUSH AO, LAFFERTY KD, LOTZ JM AND SHOSTAK W. 1997. Parasitology meets ecology on its own terms: Margolis et al. Revisited. J Parasitol 83: 575-583.

CHAMBRIER A, SCHOLZ T, KUCHTA R, POSEL P, MORTENTHALER M AND GUARDIA CC. 2006. Tapeworms (Cestoda: Proteocephalidea) of fishes from the Amazon River in Peru. Comp Parasitol 73(1): 111-120.

CHOUDHURY A, AGUIRRE-MACEDO ML, CURRAN SS, OSTROWSKI DE NUÑEZ M, OVERSTREET RM, PÉREZ-PONCE DE LEÓN G AND PORTES-SANTOS C. 2016. Trematode diversity in freshwater fishes of the Globe II: 'New World'. Syst Parasitol 93: 271-282.

CIRTWILL AR, STOUFFER DB, POULIN R AND LAGRUE C. 2016. Are parasite richness and abundance linked to prey species richness and individual feeding preferences in fish hosts? Parasitology 143: 75-86.

CURRAN SS, OVERSTREET RM AND FONT WF. 2002. Thometrema lotzi sp. nov. (Digenea, Derogenidae) from freshwater and brackish water fishes of Louisiana and Mississippi (USA). Acta Parasitol 47: 14-19.

DOGIEL VA. 1961. Ecology of the parasites of freshwater fishes. In: Dogiel VA, Petrushevsky GK and Polyanski YI (Eds), Parasitology of fishes. University Press, Leningrad, p. 1-47.

EIRAS JC, TAKEMOTO RM AND PAVANELLI GC. 2006 Métodos de estudo e técnicas laboratoriais em parasitologia de peixes. Maringá: Eduem, 199 p.

FREITAS JFT AND LENT H. 1946. Infestação de apaiaris "Astronotus ocellatus" (Agassiz) pelo nematódeo "Goeza spinulosa" (Diesing, 1839). Rev Bras Biol 6(2): 215-222.

FROESE R AND PAULY D. 2017. FishBase. World Wide Web electronic publication.www.fishbase. org, version (02/2017).

GAMA CS AND HALBOTH DA. 2004. Ictiofauna das ressacas das bacias do Igarapé da Fortaleza e do Rio Curiaú, In: Takiyama LR and Silva AQ. Diagnóstico das ressacas do estado do Amapá: bacias do Igarapé da Fortaleza e Rio Curiaú. Macapá: CPAQ/IEPA e DGEO/SEMA, p. 23-52.

GUIDELLI G, TAVECHIO WLG, TAKEMOTO RM AND PAVANELLI GC. 2011. Relative condition factor and parasitism in anostomid fishes from the floodplain of the upper Paraná River, Brazil. Vet Parasitol 177: 145-151.

KOHN A, FERNANDES BMM AND COHEN SC. 2007. South American trematodes parasites of fishes. Rio de Janeiro: Imprinta Express, 318 p.

KRITSKY DC, THATCHER VE AND BOEGER WA. 1989. Dactylogyrids from the gills of Brazilian Cichlidae with 
proposal of Sciadicleithrum gen. n. (Dactylogyridae). Proc Helminthol Soc Wash 56(2): 128-140.

LAGRUE C AND POULIN R. 2015. Measuring fish body condition with or without parasites: does it matter? J Fish Biol 87(4): 836-847.

LE CREN ED. 1951. The length-weight relationship and seasonal cycle in gonadal weight and condition in the perch (Perca fluviatilis). J Anim Ecol 20: 201-219.

LOSEE JP, FISHER J, TEEL DJ, BALDWIN RE, MARCOGLIESE DJAND JACOBSON KC. 2014. Growth and condition of juvenile Coho salmon Oncorhynchus kisutch relate positively to species richness of trophically transmitted parasites. J Fish Biol 85: 1665-1681.

LUDWIG JA AND REYNOLDS JF. 1988. Statistical ecology: a primer on methods and computing. New York: WileyInterscience, $337 \mathrm{p}$.

MARCOGLIESE DJ, GENDRON AD, PLANTE C, FOURNIER M AND CYR D. 2006. Parasites of spottail shiners (Notropis hudsonius) in the St. Lawrence River: effects of municipal effluents and habitat. Can J Zool 84: 1461-1481.

MARCOGLIESE DJ, LOCKE SA, GÉLINAS M AND GENDRON AD. 2016. Variation in parasite communities in spottail shiners (Notropis hudsonius) linked with precipitation. J Parasitol 102(1): 27-36.

MAGURRAN AE. 2004. Measuring biological diversity. Oxford: Blackwell Science, $256 \mathrm{p}$.

MALTA JCO. 1982a. Os argulídeos (Crustacea: Branchiura) da Amazônia brasileira. Aspectos da ecologia de Dolops discoidalis Bouvier 1899 and Dolops bidentata Bouvier 1899. Acta Amaz 12(3): 521-528.

MALTA JCO. 1982b. Os argulídeos (Crustacea: Branchiura) da Amazônia Brasileira, 2. Aspectos da Ecologia de Dolops geayi Bouvier, 1897 e Argulus juparanaensis Castro, 1950. Acta Amaz 12(4): 701-706.

MALTA JCO. 1984. Os peixes de um lago de várzea da Amazônia Central (Lago Janauacá, Rio Solimões) e suas relações com os crustáceos ectoparasitas (Branchiura: Argulidae). Acta Amaz 14: 355-372.

MOROZIŃSKA-GOGOL J. 2015. Changes in the parasite communities as one of the potential causes of decline in abundance of the three-spined sticklebacks in the Puck Bay. Oceanologia 57: 280-287.

NEVES LR, PEREIRA FB, TAVARES-DIAS M AND LUQUE JL. 2013. Seasonal influence on the parasite fauna of a wild population of Astronotus ocellatus (Perciformes: Cichlidae) from the Brazilian Amazon. J Parasitol 99: 718-721.
PINTO HA, CAFFARA M, FIORAVANTI ML AND MELO AL. 2015. Experimental and molecular study of cercariae of Clinostomum sp. (Trematoda: Clinostomidae) from Biomphalaria spp. (Mollusca: Planorbidae) in Brazil. J Parasitol 101(1):108-113.

RASSIER GL, PESENTI TC, PEREIRA JÚNIOR J, SILVA DS, WENDT EW, MONTEIRO CM AND BERNE MEA. 2015. Metazoan parasites of Geophagus brasiliensis (Perciformes: Cichlidae) in Patos lagoon, extreme south of Brazil. Braz J Vet Parasitol 24(4): 447-453.

REGO AA AND PAVANELLI GC. 1990. Novas espécies de cestoides proteocefalídeos parasitas de peixes não siluriformes. Rev Brasil Biol 50: 91-101.

RITOSSA L, FLORES V AND VIOZZI G. 2013. Lifecycle stages of a Posthodiplostomum species (Digenea: Diplostomidae) from Patagonia, Argentina. J Parasitol 199: 777-780.

ROHDE K, HAYWARD C AND HEAP M. 1995. Aspects of the ecology of metazoan ectoparasites of marine fishes. Inter J Parasitol 25: 945-970.

RÓZSA L, REICZIGEL J AND MAJOROS G. 2000. Quantifying parasites in samples of hosts. J Parasitol 86: 228-232.

ŠMIGA L, KOŠUTHOVÁ L, KOŠČO J, KOŠUTH P, PEKÁRIK L, FEČKANINOVÁ A AND LAZAR P. 2016. First report of Gussevia asota (Monogenea: Dactylogyridae), destructive parasite of Astronotus ocellatus (Perciformes: Cichlidae) in Europe. Biologia 71(5): 547-550.

SOARES MGM, COSTA EL, SIQUEIRA-SOUZA FK, ANJOS HDB, YAMAMOTO KC AND FREITAS CEC. 2011. Peixes de lagos do médio Rio Solimões. $2^{\mathrm{a}}$ ed., rev. Manaus: Reggo Edições, 175 p.

TAKIYAMA LR ET AL. 2012. Zoneamento ecológico econômico urbano das áreas de ressacas de Macapá e Santana, Estado do Amapá. Macapá, IEPA, 84 p.

TAVARES-DIAS M, SOUSA TES AND NEVES LR. 2014. Parasitic infections in two benthopelagic fish from Amazon: the arowana Osteoglossum bicirrhosum (Osteoglossidae) and Oscar Astronotus ocellatus (Cichlidae). Biosci J 30: 546-555.

VANHOVE MPM, HABLÜTZEL PI, PARISELLE A, ŠIMKOVÁ A, HUYSE T AND RAEYMAEKERS JAM. 2016. Cichlids: a host of opportunities for evolutionary parasitology. Trends Parasitol 32: 820-832.

ZAR JH. 2010. Biostatistical analysis. $5^{\text {th }}$ ed., New Jersey: Prentice Hall, 944 p. 